\title{
Ptosetest med is $\square$
}
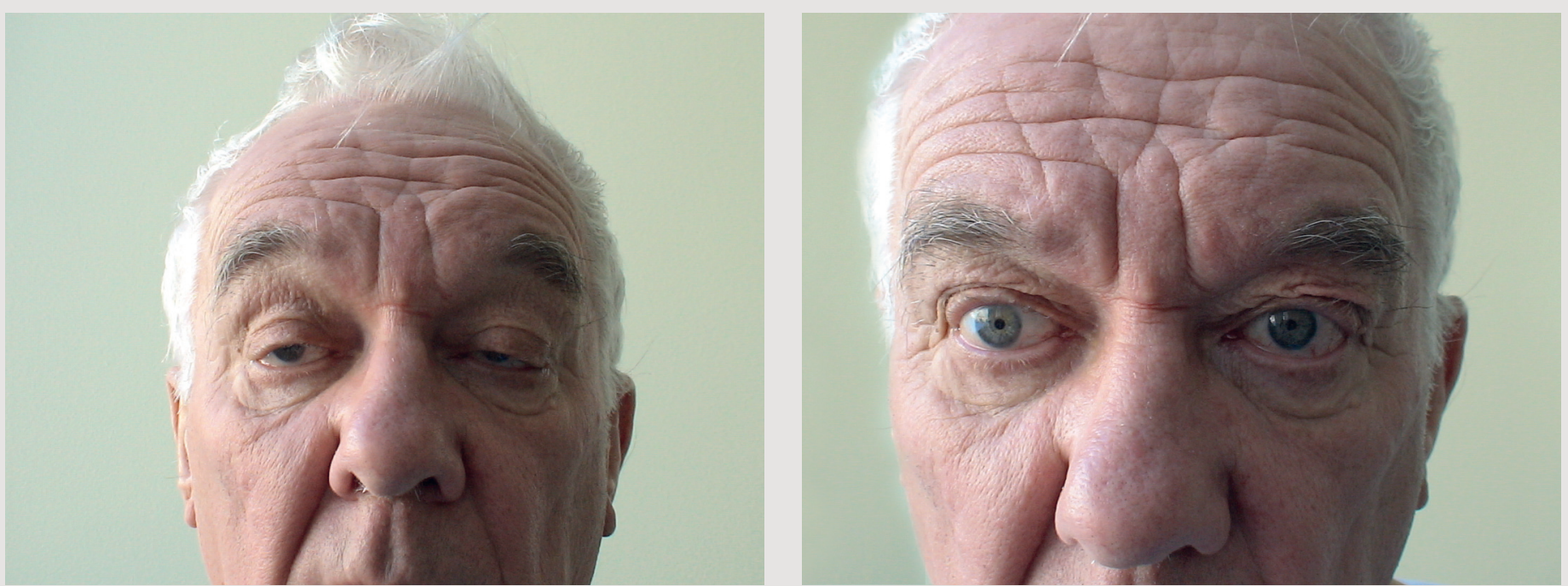

Myasthenia gravis er en prototyp på en autoimmun sykdom der antistoffer, hovedsakelig mot acetylkolinreseptor, reduserer signaloverføringen fra nerve til muskel (den nevromuskulære transmisjonen) og fører til muskulær trettbarhet og svekkelse. Ptose på ett eller begge øyne, gjerne kombinert med dobbeltsyn, forekommer tidlig i sykdomsforløpet hos majoriteten. Klinisk diagnostikk består i å påvise trettbarheten i den affiserte muskulaturen, klassisk ved ptosetest der pasienten kikker kontinuerlig oppover. Acetylkolinesterasehemmerne pyridostigmin, neostigmin og edrophonium, som øker acetylkolinnivået i den nevromuskulære synapsen, benyttes i diagnostikk og behandling av myasthenia gravis. Ved okulær myasteni kan også nedkjøling av øyelokk gi midlertidig bedring av ptose. Når temperaturen synker, øker nemlig den nevromuskulære transmisjonen. En slik istest har omtrent samme sen- sitivitet som neostigmintest, rundt $80 \%$. Farmakologisk testing ved myasthenia gravis bør utføres av spesialist.

En mann i 70-årene hadde i flere uker hatt fluktuerende ptose og tendens til diplopi. Klinisk undersøkelse viste bilateral ptose (venstre bilde) som ble midlertidig bedret etter nedkjøling (høyre bilde) utført ved at is pakket i kirurgiske gummihansker ble holdt på øyelokkene i to minutter. Video i artikkelens nettversjon viser ptosetest før og $15 \mathrm{mi}$ nutter etter at det ble gitt $0,8 \mathrm{mg}$ atropinsulfat og $1,5 \mathrm{mg}$ neostigminmetylsulfat intramuskulært. Effekten av medikamentene varte i 5-6 timer.

\section{Karl Bjørnar Alstadhaug}

alstadhaug@operamail.com

Martha Seim Realfsen

Nevrologisk avdeling

Nordlandssykehuset

Bodø
Karl Bjørnar Alstadhaug (f. 1972) er spesialist i nevrologi, overlege og førsteamanuensis.

Ingen oppgitte interessekonflikter.

Martha Seim Realfsen (f. 1983)

er lege i spesialisering i nevrologi.

Ingen oppgitte interessekonflikter.

Pasienten har gitt samtykke til at artikkelen blir publisert.

Mottatt 3.3. 2011, første revisjon innsendt 25.5. 2011, godkjent 3.6. 2011. Medisinsk redaktør Erlend T. Aasheim.

Video finnes på www.tidsskriftet.no 